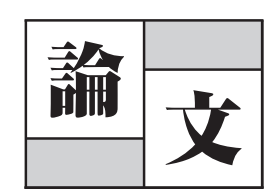

\title{
マイクロセルラー発泡成形におけるセル形態の影響因子把握
}

\author{
寺 本 弦 正*.阿 江 晴 彦*.金 井 俊 孝*
}

\section{Control Factors of Foam Morphology in Microcellular Foaming}

\begin{abstract}
Teramoto, Gensei*/Ae, Haruhiko*/Kanai, Toshitaka*
We investigated the microcellular foaming of polypropylene with supercritical nitrogen $\left(\mathrm{N}_{2}\right)$ in order to understand the most influential factors. In these experiments, an average diameter of 30 $\mu \mathrm{m}$, typically difficult to attain, was achieved for the foamed polypropylene. The most influential molding factors for the microcellular foaming process were found to be $\Delta \mathrm{P}$ (the difference between the injection pressure of the supercritical $\mathrm{N}_{2}$ in the cylinder and the back pressure of the screw), the throughput of the supercritical $\mathrm{N}_{2}$ and the resin temperature.
\end{abstract}

Key words : Microcellular/Supercritical Fluid/Foam/Nitrogen/Polypropylene

\section{1. 緒言}

超臨界流体（supercritical fluid）を用いた加工技術とし て，近年マイクロセルラー発泡成形 ${ }^{1,2)}$ が注目されている. この加工技術は超臨界状態の二酸化炭素や窒素等を発泡剂 として用いることで, 従来の物理発泡や化学発泡法に比較 し, 環境にやさしく, 流動性を向上させ, また微細な発泡 セルを有する成形品を製造することができる成形法として 注目されている，発泡セルを微細化することによる利点は, 機械的強度 ${ }^{3 \sim 5}$ ), あるいは, 光学特性, 振動特性, 寸法精 度といった広範囲の分野で報告されている(6) 8).

発泡セルのサイズは樹脂による影響が大きいと考えられ ており 甬,10), 使用される樹脂により, 数百〜数 $\mu \mathrm{m}$ という 大きな格差が見られる。このような理由から, 微細な発泡 七ル形成に有利とされる樹脂の検討についての報告 ${ }^{11) \sim 15}$ が なされている.

しかし, 微細な発泡七ル形成の成形条件因子に関する報 告はほとんどなされていない。つまり相互の関係も含めて, どの成形条件（例えば：樹脂温度, 発泡剂注入流量等) が 微細な発泡七ルの形成に影響を及ぼすのか，あるいは成形 条件だけでは微細な発泡セル形成は不可能なのか, 明確な 研究がなされていない.

* 出光興産(侏樹脂テクニカルセンター

市原市姉崎海岸 1-1（テ 299-0193）

Idemitsu Kosan Co.,Ltd.

1-1, Anesaki-Kaigan, Ichihara-city, Chiba 299-0193, Japan 2005.3.14 受理

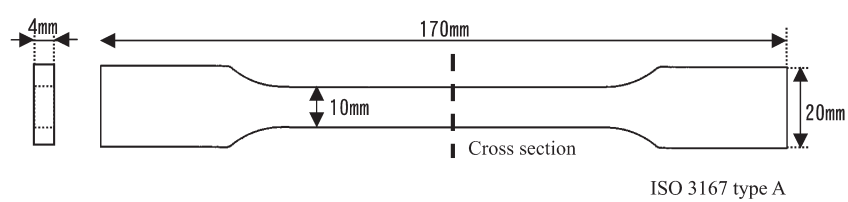

Fig. 1 Schematic of ISO dumbbell

そこで，本検討では実験計画法により，発泡セルの微細 化に影響を及ほす交互作用を含めた成形条件因子の把握と, さらには最適な条件下での微細発泡セルの形成を試みた。

材料として, 最も応用展開が期待されていながら微細な 発泡セル形成が難しいとされる結晶性樹脂のポリプロピレ ン（PP）を用いて検討を行った.

\section{2. 実験}

\section{1 発泡射出成形実験}

実験にはマイクロセルラー成形機である $\mathrm{MuCell}^{\circledR}$ 成形機 J 180 EL III（型締力 180 ton，日本製鋼所製）を使用した。 材料は IDEMITSU PP (F-300 SP : MI = 3), 超臨界流体 は微細発泡成形品が得られやすい窒素 $\left(\mathrm{N}_{2}\right)$ を用いた。試 験片として，図 1 に示すような ISO 対応ダンベル（2 個取 り）を使用した。

射出成形の基準条件として, 射出速度 $100 \mathrm{~mm} / \mathrm{sec}$, 久 クリュ回転数 $100 \mathrm{rpm}$, 樹脂温度 $220^{\circ} \mathrm{C}, \Delta \mathrm{P}(=\mathrm{SCF}$ 注 入圧一スクリ工背圧） $3 \mathrm{MPa}, \mathrm{SCF}$ 注入量 $0.5 \mathrm{~kg} / \mathrm{h}$, 軽 量化率 $8 \%$ を選定した。 また, SCF の注入時間はそれぞ れ，1秒とした。代表的な成形条件 6 因子に対し, 効率的 
に成形条件の影響を把握するため，複合実験計画法を用い た．表 1 に複合実験計画法による直交配列表を示す．本検 討では 6 因子 5 水準であるため, 45 条件の成形条件を組 み成形を行った。すべての成形で，炭酸ガス $\mathrm{CO}_{2}$ よりも 微細な発泡径が得られやすい $\mathrm{N}_{2}$ を使用し, 金型温度は $40^{\circ} \mathrm{C}$ とした。

\section{2 発泡セル形態の定量化処理方法}

得られたダンベル片の長手方向中間断面の発泡セル形態 を電子顕微鏡 JSM-6100（日本電子製）により，SEM 観 察した. 発泡セル形態の定量化は, jpg 形式の SEM 画像 を画像処理ソフトWinroofを用いておこなった。なお, 今回の検討では発泡セルを正確に定量化するために，定量 化の前に, 図 2 のように明部を画像処理することで暗部と 同化させる処理を実施した。 その結果，これまで一般に行 われてきたデジタイザー (ペンタッチによる入力形式で, 発泡セル径を定量化する方法）の結果と一致する值が得ら れ，かつ大量のデー夕を短時間で処理することができた.

\section{3 発泡セル形態の定義}

発泡セル形態は, 例えば成形品断面に図 3 に示すような 発泡セル形態が形成されていたとして,以下の指標を用いた.

$$
\text { cell number }=n
$$

$$
\text { average cell diameter }=\frac{X_{1}+X_{1}+X_{3} \cdots X_{n}}{n}=\bar{X}
$$

定義(1) は断面あたりのセル数 $n$ であり, 式(2)はセルの 直径の総合計を, セル数で除した平均セル径 $X$ である. なお, セルの直径は画像解析ソフトにより円近似して取り 扱った。

$$
\begin{aligned}
& \text { maximum cell diameter }=X_{\max } \\
& \text { minimum cell diameter }=X_{\min }
\end{aligned}
$$

定義 (3) は成形品断面あたりで最も大きいセルの直径 $X_{\max }$ であり, 定義 (4) は最も小さいセルの直径 $X_{\min }$ である.

$$
\begin{aligned}
& \text { standard deviation }=\frac{\sum_{i=1}^{n}(X \mathrm{i}-\bar{X})^{2}}{n}=\text { 分布 } 1 \\
& \text { maximum deviation }=X_{\max }-\bar{X}=\text { 分布 } 2
\end{aligned}
$$

$$
\text { rate of area }=(\text { area of cell }) / \text { area of } a \cdot b
$$

定義(5) は断面あたりのセル径分布の指標であるセルの直 径の標準偏差である (分布 1). 定義 (6) は最大セル径から 平均セル径を引いた最大偏差である（分布 2). 式 (7) は発 泡セル面積の合計を成形品断面積で除したセルの面積分率 である。

以上の 7 つを発泡セル形態指標として, SEM 写真から 2-2で述べた方法により定量化した。

\begin{tabular}{|c|c|c|c|c|c|c|}
\hline No. factors & 1 & 2 & 3 & 4 & 5 & 6 \\
\hline $\begin{array}{c}\text { Process } \\
\text { condition }\end{array}$ & $\begin{array}{c}\text { Injection } \\
\text { rate } \\
(\mathrm{mm} / \mathrm{sec})\end{array}$ & $\begin{array}{l}\text { Screw } \\
\text { Speed } \\
(\mathrm{rpm})\end{array}$ & $\begin{array}{c}\text { Resin } \\
\text { Tempera- } \\
\text { ture }\left({ }^{\circ} \mathrm{C}\right)\end{array}$ & $\begin{array}{c}\Delta \mathrm{P} \\
(\mathrm{MPa})\end{array}$ & $\begin{array}{c}\text { Througtput } \\
\text { of SCF } \\
(\mathrm{kg} / \mathrm{h})\end{array}$ & $\begin{array}{c}\text { Rate of } \\
\text { weight } \\
\text { reduction }(\%)\end{array}$ \\
\hline 1 & 140 & 150 & 230 & 4 & 0.75 & 6 \\
\hline 2 & 140 & 150 & 230 & 4 & 0.25 & 10 \\
\hline 3 & 140 & 150 & 230 & 2 & 0.75 & 10 \\
\hline 4 & 140 & 150 & 230 & 2 & 0.25 & 6 \\
\hline 5 & 140 & 150 & 210 & 4 & 0.75 & 10 \\
\hline 6 & 140 & 150 & 210 & 4 & 0.25 & 6 \\
\hline 7 & 140 & 150 & 210 & 2 & 0.75 & 6 \\
\hline 8 & 140 & 150 & 210 & 2 & 0.25 & 10 \\
\hline 9 & 140 & 50 & 230 & 4 & 0.75 & 10 \\
\hline 10 & 140 & 50 & 230 & 4 & 0.25 & 6 \\
\hline 11 & 140 & 50 & 230 & 2 & 0.75 & 6 \\
\hline 12 & 140 & 50 & 230 & 2 & 0.25 & 10 \\
\hline 13 & 140 & 50 & 210 & 4 & 0.75 & 6 \\
\hline 14 & 140 & 50 & 210 & 4 & 0.25 & 10 \\
\hline 15 & 140 & 50 & 210 & 2 & 0.75 & 6 \\
\hline 16 & 140 & 50 & 210 & 2 & 0.25 & 10 \\
\hline 17 & 60 & 150 & 230 & 4 & 0.75 & 10 \\
\hline 18 & 60 & 150 & 230 & 4 & 0.25 & 6 \\
\hline 19 & 60 & 150 & 230 & 2 & 0.75 & 6 \\
\hline 20 & 60 & 150 & 230 & 2 & 0.25 & 10 \\
\hline 21 & 60 & 150 & 210 & 4 & 0.75 & 6 \\
\hline 22 & 60 & 150 & 210 & 4 & 0.25 & 10 \\
\hline 23 & 60 & 150 & 210 & 2 & 0.75 & 10 \\
\hline 24 & 60 & 150 & 210 & 2 & 0.25 & 6 \\
\hline 25 & 60 & 50 & 230 & 4 & 0.75 & 6 \\
\hline 26 & 60 & 50 & 230 & 4 & 0.25 & 10 \\
\hline 27 & 60 & 50 & 230 & 2 & 0.75 & 10 \\
\hline 28 & 60 & 50 & 230 & 2 & 0.25 & 6 \\
\hline 29 & 60 & 50 & 210 & 4 & 0.75 & 10 \\
\hline 30 & 60 & 50 & 210 & 4 & 0.25 & 6 \\
\hline 31 & 60 & 50 & 210 & 2 & 0.75 & 6 \\
\hline 32 & 60 & 50 & 210 & 2 & 0.25 & 10 \\
\hline 33 & 100 & 100 & 220 & 3 & 0.5 & 8 \\
\hline 34 & 180 & 100 & 220 & 3 & 0.5 & 8 \\
\hline 35 & 20 & 100 & 220 & 3 & 0.5 & 8 \\
\hline 36 & 100 & 180 & 220 & 3 & 0.5 & 8 \\
\hline 37 & 100 & 30 & 220 & 3 & 0.5 & 8 \\
\hline 38 & 100 & 100 & 240 & 3 & 0.5 & 8 \\
\hline 39 & 100 & 100 & 200 & 3 & 0.5 & 8 \\
\hline 40 & 100 & 100 & 220 & 5 & 0.5 & 8 \\
\hline 41 & 100 & 100 & 220 & 1 & 0.5 & 8 \\
\hline 42 & 100 & 100 & 220 & 3 & 1 & 8 \\
\hline 43 & 100 & 100 & 220 & 3 & 0.1 & 8 \\
\hline 44 & 100 & 100 & 220 & 3 & 0.5 & 0 \\
\hline 45 & 100 & 100 & 220 & 3 & 0.5 & 24 \\
\hline
\end{tabular}

また，発泡セル形態に影響を及ぼす成形条件因子として は, 図 4 に示す因子に着目した。これらの 6 つの成形条件 因子を検討因子として複合実験計画法（6因子 5 水準）に 基づき（1 次計画が 32 条件， 2 次計画が 13 条件）全 45 条 件の成形を行った（表 1). 45 条件分の成形条件と結果（セ
Table 145 process conditions by design of experiment 


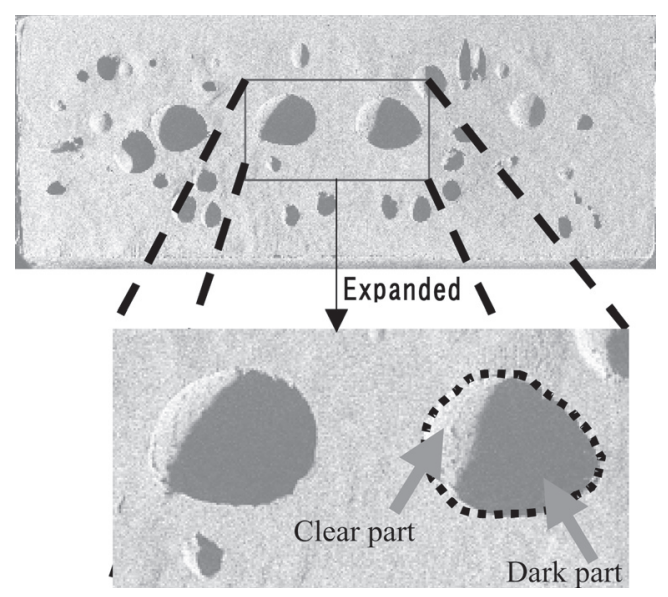

Fig. 2 Digitalization of Foaming Cell Morphology

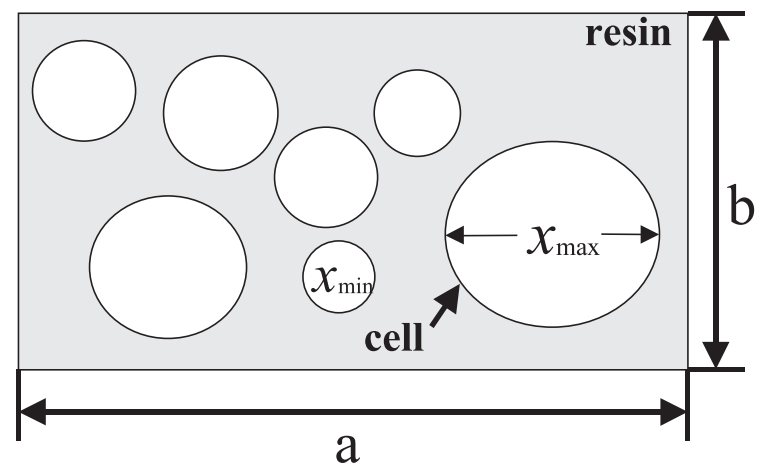

Fig. 3 Schematic of foaming morphology

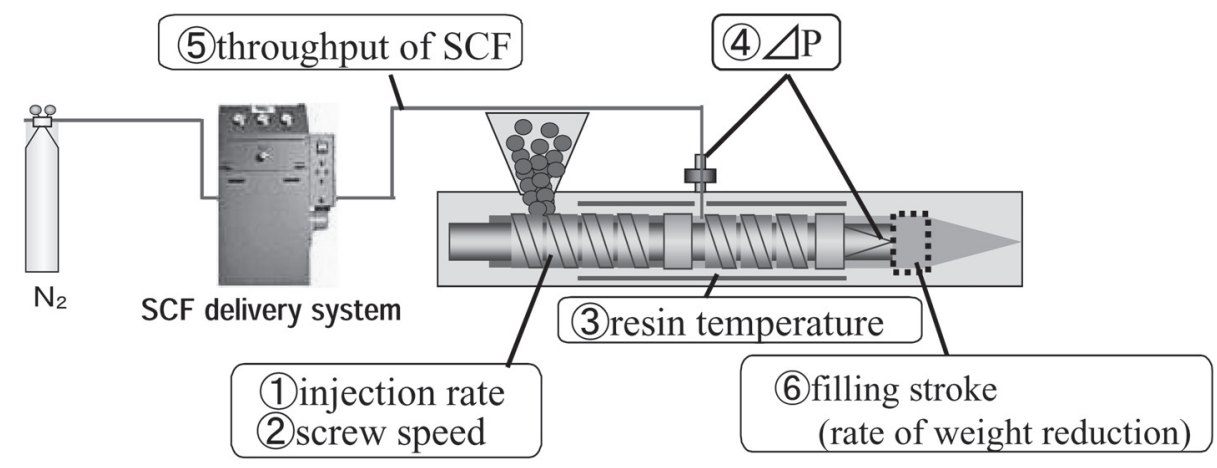

Fig. 4 Various molding factors in MuCell process

Table 2 Average relative error of foaming morphology indexes

\begin{tabular}{c|c|c|c}
\hline $\mathrm{Y}$ & $\begin{array}{c}\text { maximum } \\
\text { cell diameter }\end{array}$ & distribution 2 & rate of area \\
\hline $\begin{array}{c}\text { average } \\
\text { relative error }\end{array}$ & $25 \%$ & $27 \%$ & $14 \%$ \\
\hline
\end{tabular}

(a) Indexes of small error

\begin{tabular}{c|c|c|c|c}
\hline $\mathrm{Y}$ & $\begin{array}{c}\text { number of } \\
\text { cell }\end{array}$ & $\begin{array}{c}\text { average cell } \\
\text { diameter }\end{array}$ & $\begin{array}{c}\text { minimum cell } \\
\text { diameter }\end{array}$ & distribution 1 \\
\hline $\begin{array}{c}\text { average } \\
\text { relative error }\end{array}$ & $53 \%$ & $42 \%$ & $190 \%$ & $174 \%$ \\
\hline
\end{tabular}

(b) Indexes of large error

ル形態）を，

$$
\begin{aligned}
y=\alpha_{00} & +\alpha_{01} X_{1}+\alpha_{02} X_{2}+\alpha_{03} X_{3}+\alpha_{04} X_{4}+\alpha_{05} X_{5}+\alpha_{06} X_{6} \\
& +\alpha_{11} X_{1}^{2}+\alpha_{22} X_{2}^{2}+\alpha_{33} X_{3}^{2}+\alpha_{44} X_{4}^{2}+\alpha_{55} X_{5}^{2}+\alpha_{66} X_{6}^{2} \\
& +\alpha_{12} X_{1} X_{2}+\alpha_{13} X_{1} X_{3}+\alpha_{14} X_{1} X_{4}+\alpha_{15} X_{1} X_{5}+\alpha_{16} X_{1} X_{6} \\
& +\alpha_{23} X_{2} X_{3}+\alpha_{24} X_{2} X_{4}+\alpha_{25} X_{2} X_{5}+\alpha_{26} X_{2} X_{6} \\
& +\alpha_{34} X_{3} X_{4}+\alpha_{33} X_{3} X_{5}+\alpha_{36} X_{3} X_{6} \\
& +\alpha_{45} X_{4} X_{5}+\alpha_{46} X_{4} X_{6} \\
& +\alpha_{56} X_{5} X_{6}+\varepsilon
\end{aligned}
$$

それぞれ式(8)へ代入し最小 2 乗法による 2 次多項式近似 により, 係数 $\alpha$ を求めた.

$y$ は発泡セルの指標, $X_{n}$ は各成形条件, $\varepsilon$ は誤差である. 算出された係数 $\alpha$ の大きさが寄与率の大きさであるので, 係数の大きさによりセル形態への影響度の大きさを判断した.
また，式(9)より平均相対誤差を確認した.

average relative error $=\left(\sum_{i=1}^{45} \frac{\left|y_{i}^{*}-y_{i}\right|}{y_{i}} / 45\right) \times 100$

平均相対誤差は, 発泡セルの SEM 写真を定量化して得ら れた各発泡セル形態(実測值 $: y_{i}$ ) と, 式 (8)により算出さ れた各発泡セル形態（計算值： $y_{i}^{*}$ ) との差を表す量である.

\section{3 . 結果と考察}

\section{1 発泡セル形態への影響因子抽出}

平均相対誤差の算出結果を表 2 に示す。この結果により, 指標によって平均相対誤差の值が大きく異なることがわ かった。 ここで平均相対誤差が大きいということは, 近似 式が実際の実測值の変動を正確に表すことができていない 


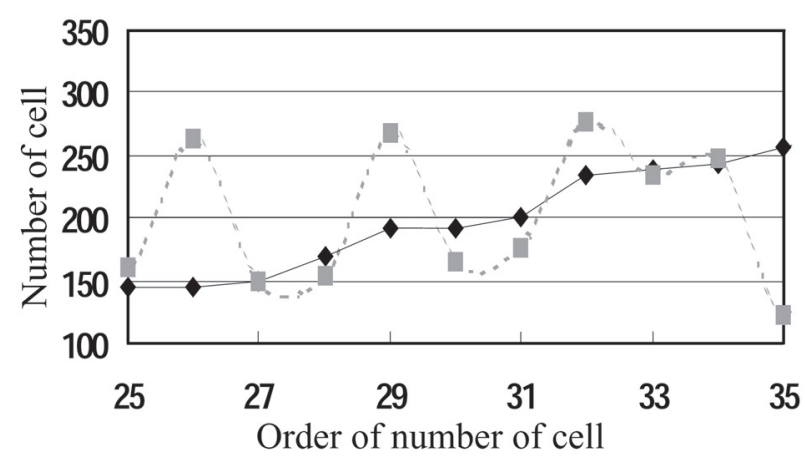

(a) Number of cell $<$ average relative error $53 \%>$

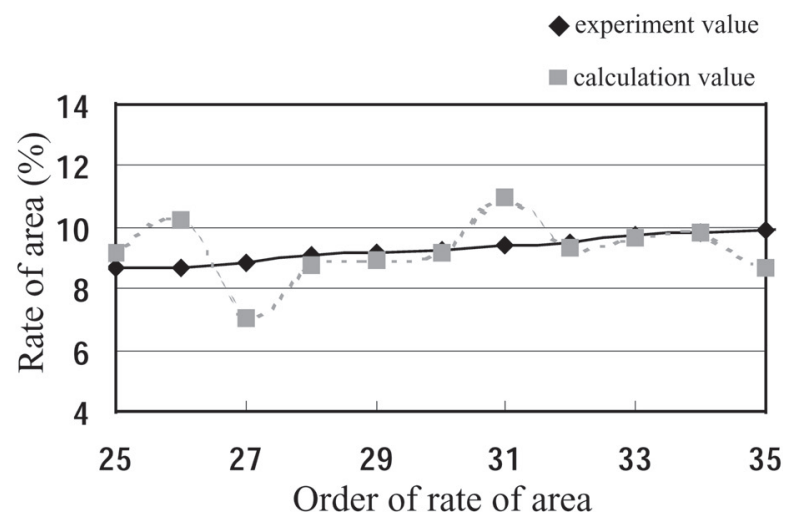

(b) Rate of area < average relative error 14\%>

Fig. 5 Comparison of average relative error

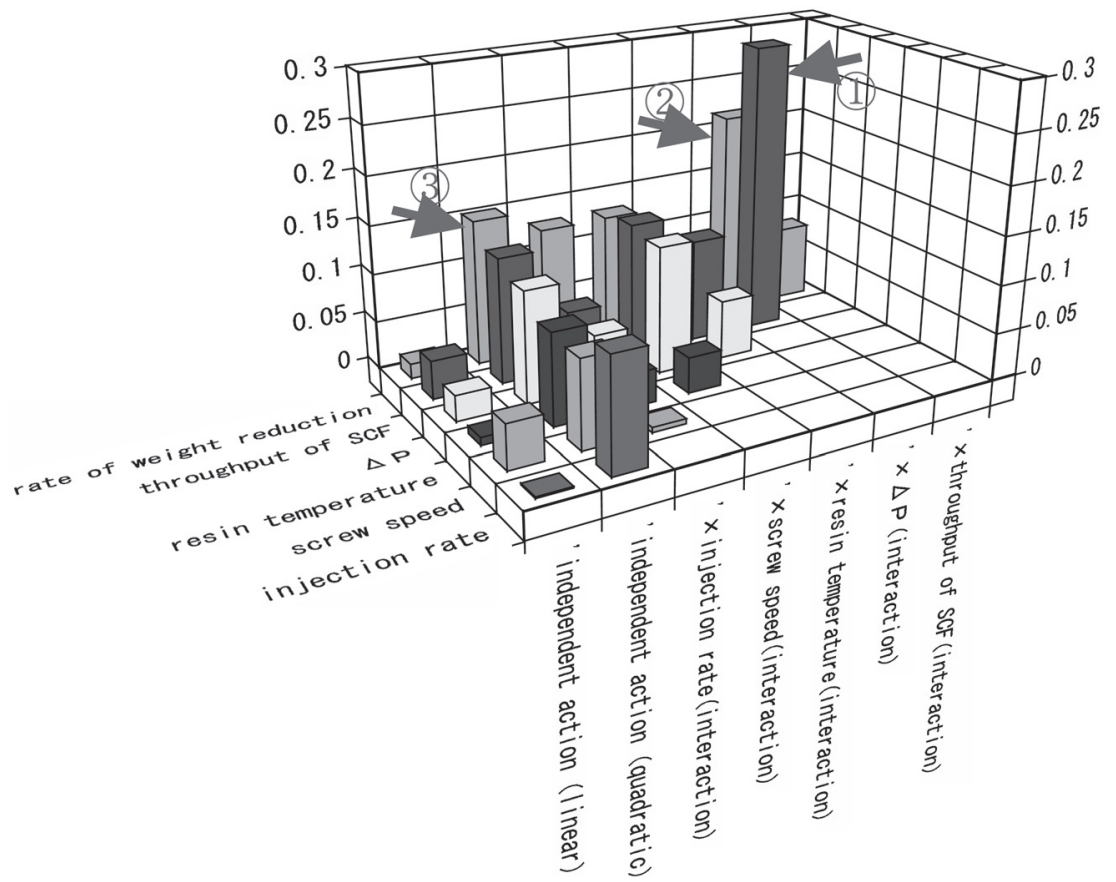

Fig. 6 Relation between molding factor and contribution rate for maximum cell diameter

ということである．図 5 にその例を示す，セル数順，セル 面積分率順とは 45 の成形条件において，発泡セル形態の 定量化した結果を各指標で大きい順にそれぞれ並べ替えた ものである.困は一例として 25 番目〜35 番目を抜粋した ものである。図 5(a)では実線部の実測值に対し，破線部

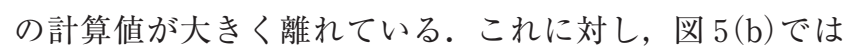
破線部の計算值が実線部の実測值によく追随していること がわかる。

そのため, 以下の検討には平均相対誤差の小さい, 最大 セル径, 分布 2 , セルの面積分率を用いることにした。そ してこれらの 3 つのセルの指標に対し，それぞれに最も影 響を及ぼす成形条件因子を解析した。図 6 に最大セル径に 及ぼす各成形条件因子の寄与率の解析結果を示す。なお, 各寄与率の值は絶対值を取った值である.

この結果から, 最も寄与度が高いものは SCF 注入流量・ $\Delta \mathrm{P}$ の交互作用（交互作用：Yの值が $X_{i}, X_{j}$, ただし $i \neq j$ の 2 次関数で表される関係）であった. 2 番目に寄与率が
大きいものは樹脂充填量（軽量化率）・ $\Delta \mathrm{P}$ の交互作用で あった. 3 番目は樹脂充填量 (軽量化率) の 2 次の独立作 用 (独立作用：Yと X が 1 次関数か, 2 次関数で表される 関係）であった，同様の比較を分布 2 ，七ルの面積分率に ついても行なった.

それらの結果をまとめたものを表 3 に示す. 最大セル径, セルの面積分率，分布 2 のすべてに共通する影響度の高い 因子は“ $\Delta \mathrm{P}$ と SCF 注入量”であることがわかった。ま た，セル面積分率，分布 2 においては樹脂温度の影響が高 いという解析結果が得られた。また軽量化率に関しても, 同様な結果が得られた。これらの結果を踏まえ，2次多項 式近似により得られた関数から，発泡セル形態と影響度の 高い成形条件の相対関係を調べた。

図 7 に最大七ル径と $\Delta \mathrm{P} \cdot \mathrm{SCF}$ 流量の関係を示す。これ より, $\Delta \mathrm{P}$ の最大值 $(5 \mathrm{MPa}), \mathrm{SCF}$ 注入量の最大值 $(1.0$ $\mathrm{kg} / \mathrm{h})$ において図の実線で囲んだ部分が最適值という解 析結果が得られた。つまり，SCFの全体量を多くするこ 
Table 3 Relation between molding factors and foaming morphology

\begin{tabular}{|c|c|c|c|c|}
\hline & & \multicolumn{3}{|c|}{ Order of contribution } \\
\hline & & 1 & 2 & 3 \\
\hline \multirow{6}{*}{ 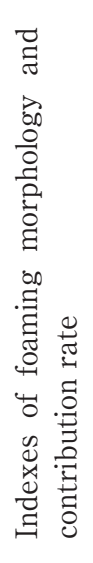 } & $\begin{array}{l}\text { Maximum cell } \\
\text { diameter }\end{array}$ & $\begin{array}{l}\Delta \mathrm{P} \cdot \\
\text { Throughput of } \\
\text { SCF }\end{array}$ & $\begin{array}{c}\Delta \mathrm{P} \cdot \text { Rate of } \\
\text { weight } \\
\text { reduction }\end{array}$ & $\begin{array}{l}\text { Rate of weight } \\
\text { reduction }\end{array}$ \\
\hline & Contribution rate & 0.298 & 0.214 & 0.150 \\
\hline & Rate of area & $\begin{array}{c}\text { Injection } \\
\text { rate } \cdot \text { Resin } \\
\text { temperature }\end{array}$ & $\begin{array}{c}\Delta \mathrm{P} \cdot \text { Rate of } \\
\text { weight } \\
\text { reduction }\end{array}$ & $\begin{array}{c}\Delta \mathrm{P} \cdot \\
\text { Throughput of } \\
\text { SCF }\end{array}$ \\
\hline & Contribution rate & 4.13 & 3.79 & 3.25 \\
\hline & Distribution 2 & $\begin{array}{l}\text { Resin } \\
\text { temperature } \cdot \text { Rate } \\
\text { of weight } \\
\text { reducution }\end{array}$ & $\begin{array}{c}\Delta \mathrm{P} \cdot \\
\text { Throughput of } \\
\text { SCF }\end{array}$ & Injection rate \\
\hline & Contribution rate & 0.258 & 0.228 & 0.196 \\
\hline
\end{tabular}

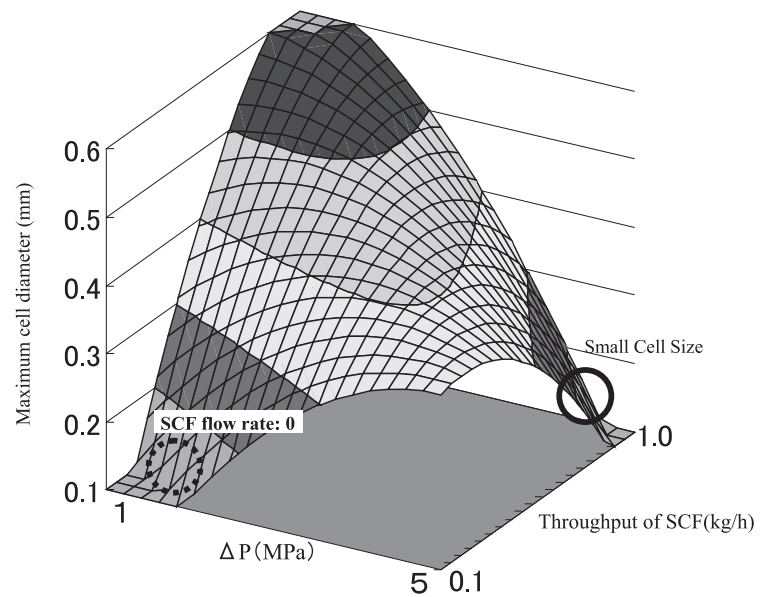

Fig. 7 Relation between foaming cell diameter of maximum, $\Delta \mathrm{P}$ and $\mathrm{SCF}$ injection value

とで最大セル径は，最小值になるということである。また， $\Delta \mathrm{P}$ の最小值 $(1 \mathrm{MPa}), \mathrm{SCF}$ 注入量の最小值 $(0.1 \mathrm{~kg} / \mathrm{h})$ も同様な傾向が見られるが (破線で囲んだ部分)，これは 実質 SCF の全体量がゼロに近づく值である。つまり，発 泡が起こらない領域と推察でき, 計算上この様な曲面形状 になるものと考えられる。

この解析結果を確認するために検証実験を行ない, その 正誤性を確認した。

\section{2 解析結果の検証}

図 8 に検討前の試料と, 解析結果による $\Delta \mathrm{P}=5 \mathrm{MPa}$, $\mathrm{SCF}$ 注入流量 $=1.0 \mathrm{~kg} / \mathrm{h}$ で成形を行なった試料の断面の SEM 写真を示す.

なお，全ての検証実験で軽量化率は $13 \%$ とした。(a)は 検討前で，最も小さい平均セル径を記録した試料の SEM 写真である.これに対して (b)のサンプルは検討後の試料 で, 平均セル径は $30 \mu \mathrm{m}$ である. これは従来の平均発泡 セル径と比較すると $1 / 3$ の值である. しかし, 図 8(b)で はボイド（大きな空孔）があり，七ル径が均一ではない. そこで, SCF 量を調整することで，このボイドを消すこ とを試みた。

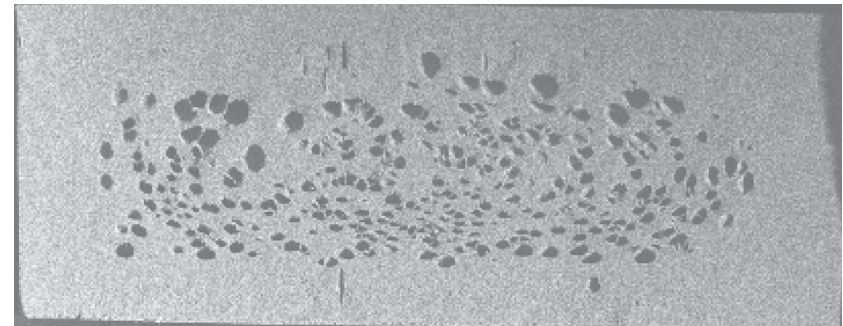

(a)

average cell diameter $96 \mu \mathrm{m}$

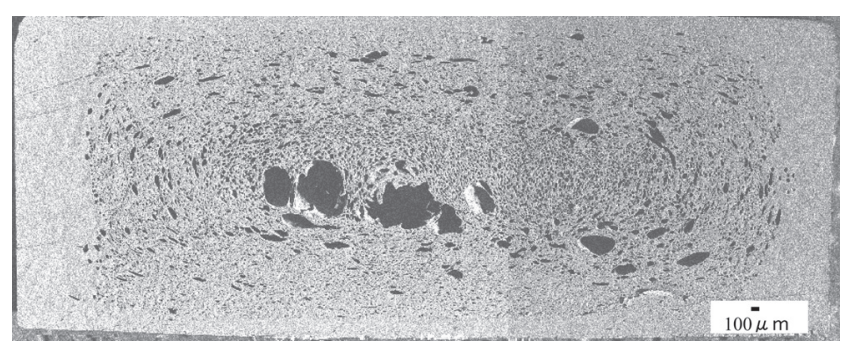

(b)

Average cell diameter $30 \mu \mathrm{m}$ $\Delta \mathrm{P}=5 \mathrm{MPa}$, throughput of $\mathrm{SCF}=1 \mathrm{~kg} / \mathrm{h}$

Fig. 8 SEM micrographs of polypropylene foaming before this examination (a) and after (b)

その結果, 図 9 の (a)から (b)へ SCF 量が少なくなると 共に，ボイドの発生率が高くなることが示された。また眓 8(b) と合わせて考察すると，ボイドの発生を抑えるため には適正值がある事がわかった。図 8, 図 9 の(b)で共に ボイドが多くなっている理由は, 図 8(b)ではSCF の飽和 溶解度よりも更に多くの SCF が注入されたためにボイド が発生していると考えられる。図 $9(\mathrm{~b})$ の場合は，樹脂中 の SCF 量が少ない状態より発泡形成が開始されたと考え られる。したがって古典的核形成理論 ${ }^{16)} に よ り$ 核形成数が 少ないため, 発泡セルが肥大化したと考えられる.

なお，図 9(b)で，特に発泡セルが大きい部分は，三面 冷却付近の箇所であるため, 体積収縮が大きいと考えられ る.この体積収縮のため, 発泡セルが合一し, 肥大化した ものと考えられる．更に他の成形条件の影響を確認するた 


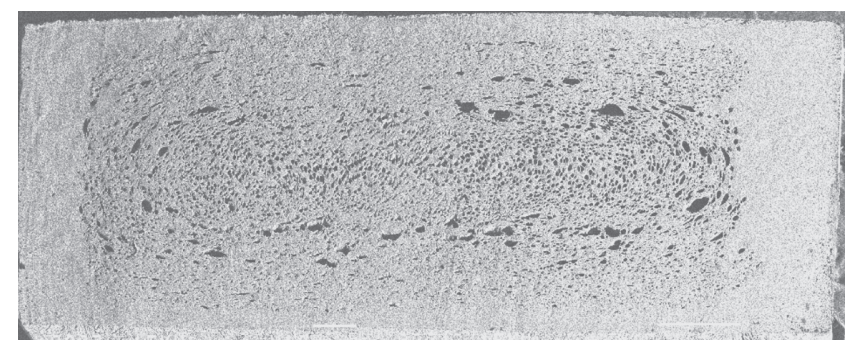

(a)

$\Delta \mathrm{P}=3 \mathrm{MPa}$, throughput of $\mathrm{SCF}=0.5 \mathrm{~kg} / \mathrm{h}$

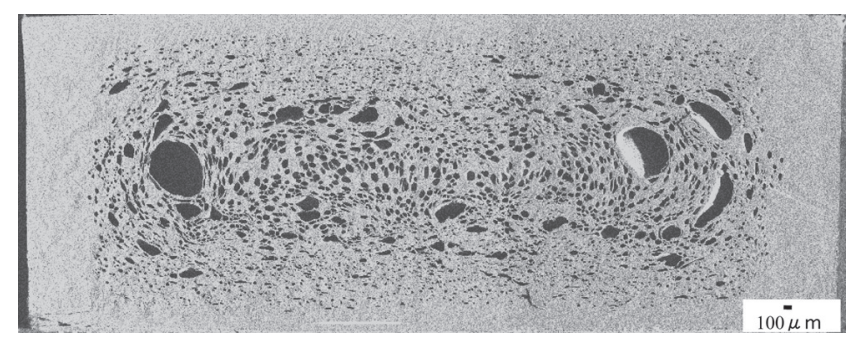

(b)

Other conditions : injection rate $=60 \mathrm{~mm} / \mathrm{sec}$, screw speed $=75 \mathrm{rpm}$, resin temperature $=235^{\circ} \mathrm{C}, \Delta \mathrm{P}=2 \mathrm{MPa}$, throughput of $\mathrm{SCF}=0.25 \mathrm{~kg} / \mathrm{h}$

Fig.9 SEM micrographs of polypropylene foaming by various SCF conditions

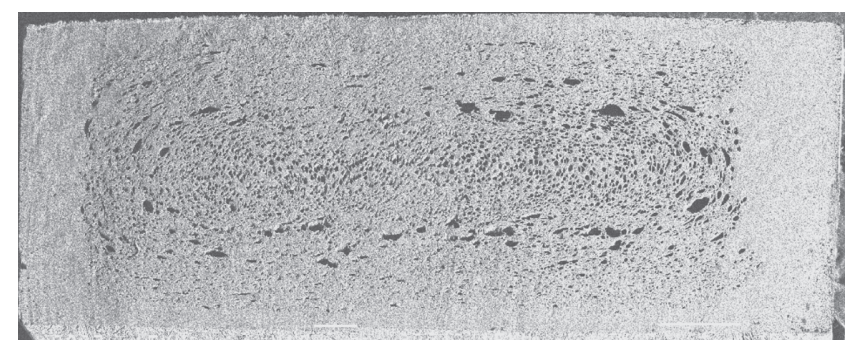

(a)

Resin temperature $235^{\circ} \mathrm{C}$

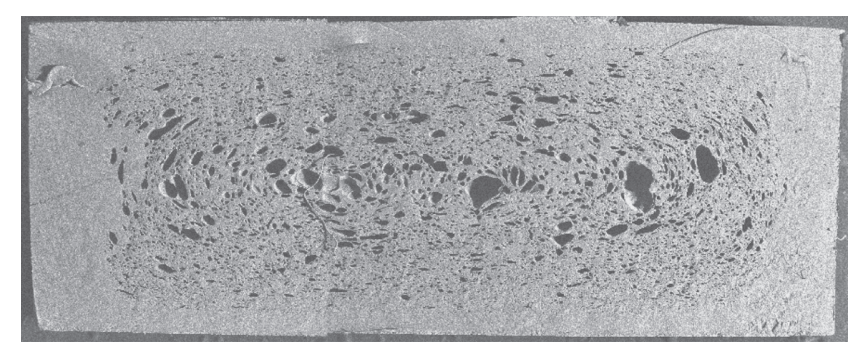

(b)

Resin temperature $220^{\circ} \mathrm{C}$

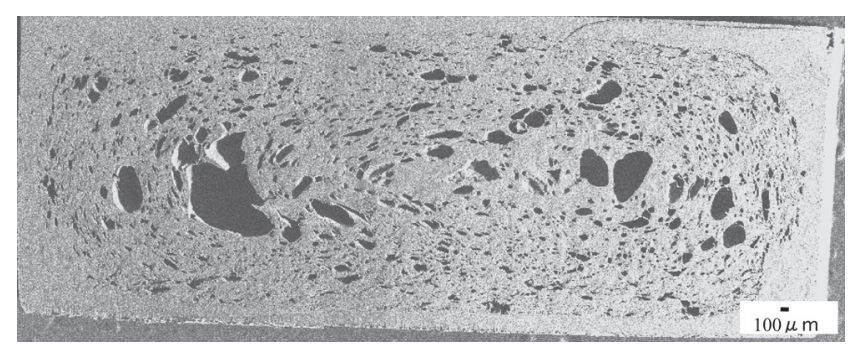

(c)

Resin temperature $200^{\circ} \mathrm{C}$

Other conditions : injection rate $=60 \mathrm{~mm} / \mathrm{sec}$, screw speed $=75 \mathrm{rpm}, \Delta \mathrm{P}=$ $3 \mathrm{MPa}$, throughput of $\mathrm{SCF}=0.5 \mathrm{~kg} / \mathrm{h}$

Fig. 10 SEM micrographs of polypropylene foaming at various temperatures

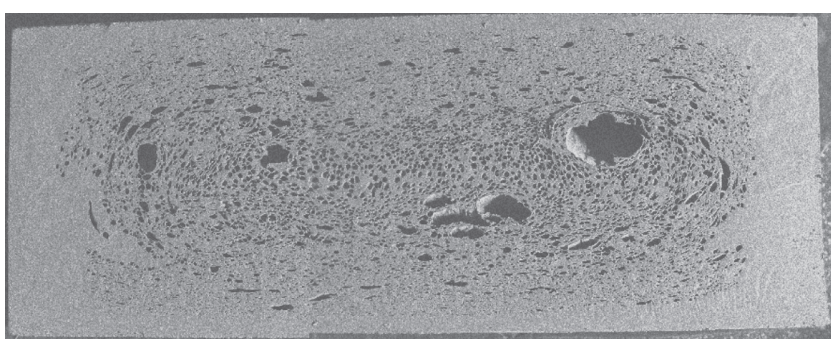

(a)

Screw speed $180 \mathrm{rpm}$

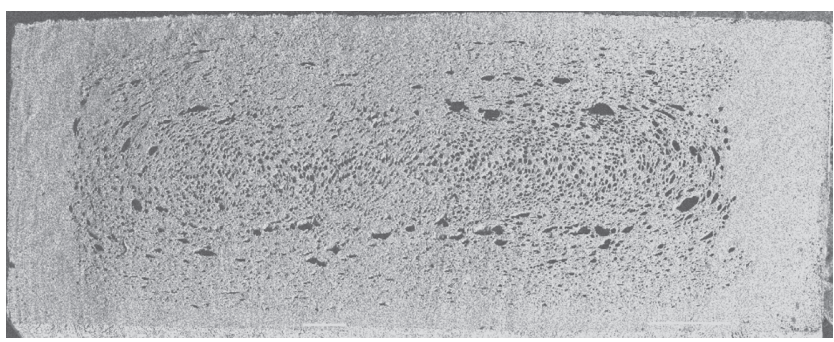

(b)

Screw speed $75 \mathrm{rpm}$

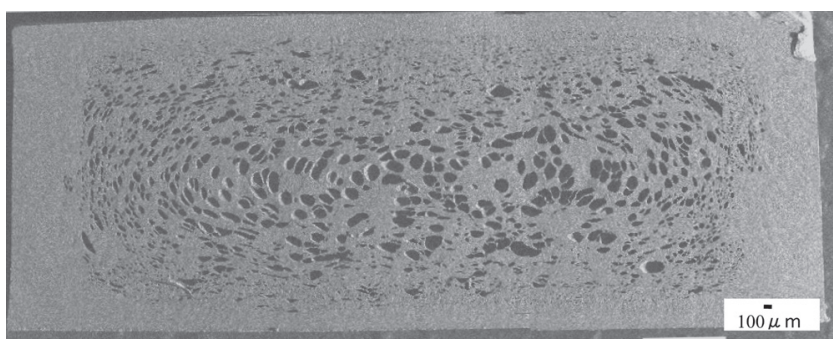

(c)

Screw speed $30 \mathrm{rpm}$

Other conditions : injection rate $=60 \mathrm{~mm} / \mathrm{sec}$, resin temperature $=235^{\circ} \mathrm{C}$, $\Delta \mathrm{P}=3 \mathrm{MPa}$, throughput of $\mathrm{SCF}=0.5 \mathrm{~kg} / \mathrm{h}$

Fig. 11 SEM micrographs of polypropylene foaming at various screw speeds

めに検討を行なった.

図 10 には, 最適な SCF の注入条件であった $\Delta \mathrm{P}=3 \mathrm{MPa}$, $\mathrm{SCF}$ 注入流量 $0.5 \mathrm{~kg} / \mathrm{h}$ の条件で, 樹脂温度を変化させて 成形を行ったサンプルの断面写真を示す.

写真のように樹脂温度が高くなるにつれ，ボイドの発生 度合いが低くなることが明らかになった。これは $\mathrm{N}_{2}$ の時 のヘンリー則に従い，樹脂温度が高いと SCF の溶解度が 高くなることによると考えられる.つまり, SCF 量が多く なれば核形成数が多くなるため, 樹脂温度が高くなると発 泡七ル径は小さくなり, 七ル径は均一になると考えられる. 一方，影響度が低いと推定される因子に対しても，スク リ工回転数, 射出速度を例として検証を行い, 解析の整合 性を確認した．図 11 にスクリュ回転数を変化させて成形 したサンプル断面の SEM 写真を示す.

写真の示すように，ボイドを無くし発泡セル径を均一に するには，スクリュ回転数は最適速度があることがわかっ

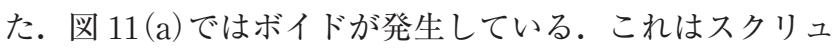
回転数が速すぎるため, SCF の分散が均一にできていな いか，または計量終了から充填までの滞留時間が長いため 一度溶解したSCF が溶出したものと考えられる。また, 図 $11(\mathrm{c})$ ではボイドの発生は認められないが，セル径が図 


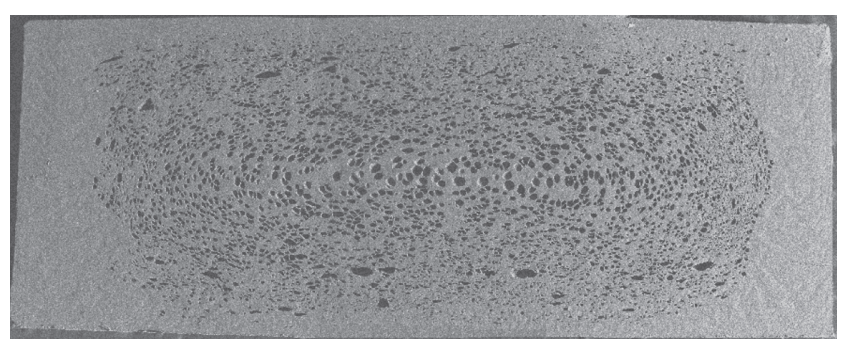

(a)

Injection rate $180 \mathrm{~mm} / \mathrm{sec}$

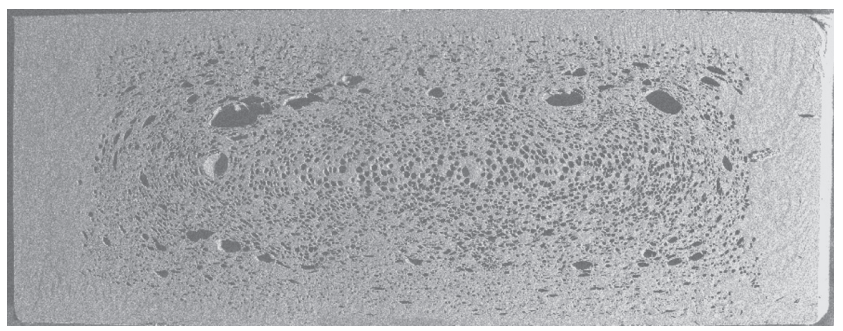

(b)

Injection rate $100 \mathrm{~mm} / \mathrm{sec}$

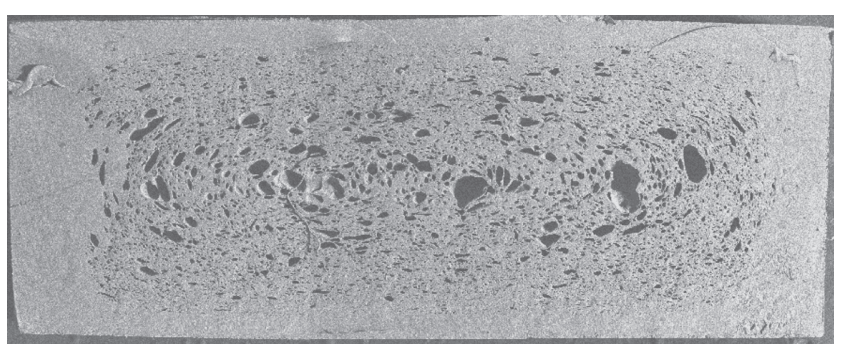

(c)

Injection rate $20 \mathrm{~mm} / \mathrm{sec}$

Other conditions : screw speed $=75 \mathrm{rpm}$, resin temperature $=235^{\circ} \mathrm{C}, \Delta \mathrm{P}$ $=3 \mathrm{MPa}$, throughput of $\mathrm{SCF}=0.5 \mathrm{~kg} / \mathrm{h}$

Fig. 12 SEM micrographs of polypropylene foaming at various injection speed

11(b)よりも大きくなっていることがわかる.これはスク リ工回転速度が遅すぎたため, SCF が均一に分散できず に樹脂中に濃度分布が生じ，分散が局所的であるために， 発泡時にSCF が局在化し, 発泡セルが大きくなったと考 えられる。

最後に, 射出速度を変化させて成形した試料断面の SEM 写真を図 12 に示す. 射出速度が速くなると共に, ボイド 数が減少し, 発泡七ル径は小さくなっていくことが示され た. 射出速度が速くなれば，一般に射出圧力も高くなる. ヘンリー則によると，高圧下では SCF の溶解度が高くな るので, 前述の SCF 量の時と同様な結果が生じると考え られる。

以上，成形条件と発泡七ル形態の関係を検討した結果， 発泡セル形態に大きな影響を及ぼすと考えられる成形条件 因子は, (1) SCF 量, (2) $\Delta \mathrm{P}$, (3)樹脂温度であることがわかっ た。また，射出速度やスクリ工回転数については発泡の均 一化に影響を及ぼしていることがわかった。これらの因子
は最適な成形条件が存在し，それらの適正な条件を選定す ることにより，発泡核剤の添加や複合化していないニート $\mathrm{PP}$ でも, $30 \mu \mathrm{m}$ の均一な PP 発泡射出成形品が得られる ことが判明した。

\section{4. 結言}

PP を用いたマイクロセルラー成形で実験計画法を用い た検討の結果，6つの成形条件因子の中から，発泡セル形 態に大きな影響を及ぼす因子を抽出することができた。そ の影響因子はSCF 注入流量と $\Delta \mathrm{P}$, および樹脂温度であった。 この解析結果に基づき検証実験をおこなったところ，発 泡セル微細化のための成形条件としては

(1)飽和溶解度以下で SCF の注入量を多くする

(2)樹脂温度を高くする

であることがわかった。しかし，これらの成形条件には適 正值があり，この条件を外れると発泡セルは微細化しない ことがわかった。適正な成形条件であれば，ニート PP で も微細な（平均 $30 \mu \mathrm{m}$ ) 発泡セルの形成が可能であるこ とが明らかになった。

\section{参 考 文 献}

1) Waldman, F. A. and Thesis, M. : Mechanical Engineering, M.I.T., January (1981)

2 ) Colton, J. S. and Suh, N.P. : Advanced Manufacturing Process, 1 (3), 314 (1986)

3 ) Kumar, V. and Seeler, K. A. : SPE ANTEC Technical Papers (1993)

4 ）新保實：高分子加工, 45(7), 13 （1996）

5 ) Kanai, T. and Kawato, H. and Goda, H. and Otsuki, Y. : Proceedings of Polymer-Supercritical Fluid Systems and Foams 13-18 (2003)

6 ）株本明：成形加工，11(12)，966（1999）

7 ) 株本明：プラスチック成形加工学会第 49 回講演会, 15 (2000)

8 ）株本明他：成形加工シンポジア’98，161（1998）

9 ) Bradly, M. B. and Phillips, E. M. : Cellular Polymers, 20 (22), (1991)

10）水本智裕他：成形加工シンポジア’00，211（2000）

11）津田文明：プラスチックスエージ，47(1)，123(2001)

12）川東宏至，合田宏史，金井俊孝：成形加工 '02, 115 (2002)

13）宮崎広隆：成形加工’02，117（2002）

14) Abiko, T. and Kawato, H. and Kanai, T. : Proceedings of Polymer-Supercritical Fluid Systems and Foams, 36-45 (2003)

15）大梘安彦, 金井俊孝, 瀧健太郎, 大嶋正裕 : 成形加工, 15 (9) , 638 (2003)

16）大嶋正裕：プラスチック成形加工学会, 第 52 回講演 会資料，1（2002） 